\title{
Uterine Sarcomas: 10 Years of Experience at a Single Institution
}

\author{
Gazi Yıldız, (1) Elif Cansu Gündoğdu, (1) Gülfem Başol, \\ (1) Emre Mat, (1) Ahmet Kale
}

Department of Gynecology and Obstetrics, University of Health Sciences, Kartal Dr. Lütfi Kırdar Training and Research Hospital, İstanbul,

Turkey

Submitted: 05.08.2019 Accepted: 16.10.2019

Correspondence: Gazi Yıldız, Sağlık Bilimleri Üniversitesi, Kartal Dr. Lütfi Kırdar Eğitim ve Araştırma Hastanesi, Kadın Hastalıkları ve Doğum Anabilim Dalı, İstanbul, Turkey

E-mail: drgaziyildiz@gmail.com

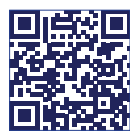

Keywords: Adenosarcoma; carcinosarcoma; endometrial stromal sarcoma; leiomyosarcoma; uterine sarcoma. Attribution-NonCommercial 4.0 International License.

\begin{abstract}
Objective: The present study aims to evaluate the sociodemographic characteristics and clinical management of patients with uterine sarcoma.
\end{abstract}

Methods: Retrospective analysis of 55 patients, who were diagnosed with uterine sarcomas between January I, 2004-January I, 20I4, was performed. Sociodemographic characteristics, methods used in diagnosis and treatment processes were investigated by accessing the medical files of the patients. All patients were contacted by telephone to obtain information about disease progression and recurrence. Patients' death reports were obtained from the national database of the Ministry of Health and the findings were analyzed statistically.

Results: In this study, 55 cases of uterine sarcoma, of whom 3 I carcinosarcomas $(56.4 \%)$, I 5 leiomyosarcomas (27.3\%), six endometrial stromal sarcomas (10.9\%) and three adenosarcomas $(5.5 \%)$ were analyzed. The median age was $60.75 \pm 12.74$ (min-max: 33-86). Fortythree $(78.2 \%)$ patients were in postmenopausal period. Twenty-seven (47.3\%) of these patients were diagnosed by endometrial sampling, 17 (30.9\%) patients were diagnosed by frozen section, II (20\%) patients were diagnosed by hysterectomy and one (I.8I\%) patient was diagnosed by myomectomy. Three patients had distant metastases at the time of diagnosis. According to FIGO (International Federation of Gynecology and Obstetrics) 2009, $65.5 \%$ of the patients were diagnosed at stage I. $58.5 \%$ of the patients who underwent surgery were operated by gynecologist-oncologist. Total abdominal hysterectomy with bilateral salping-oopherectomy was performed in 52 patients $(94.5 \%)$. Pelvic lymph node dissection was performed in 28 patients (5I\%). The mean survival time was 47 months in carcinosarcoma, 49.6 months in leiomyosarcoma, 84.8 months in endometrial stromal sarcoma and 68.7 months in adenosarcoma. Until the last date of collecting data, January 2019, 37 patients (67.3\%) died.

Conclusion: Uterine sarcomas are rare tumors with poor prognosis even in the early stages. Each histological type should be evaluated separately. Surgery is the main treatment method in uterine sarcoma. The role of adjuvant therapy is controversial.

\section{INTRODUCTION}

Uterine sarcomas are rare neoplasms of the genital system developing from tissues of mesodermal origin as myometrial smooth muscle, endometrial stroma or more rarely from any connective tissue. They constitute approximately $1 \%$ of female genital tract malignancies and approximately $3-8 \%$ of all malignant uterine neoplasms. ${ }^{[1,2]}$ They are classified histologically as carcinosarcoma (50\%), leiomyosarcoma (30\%), endometrial stromal sarcoma (15\%) and adenosarcoma (5\%). Due to their rapid growth, early hematogenous and lymphogenous spread, their prognosis is worse than carcinomas.

Since carcinosarcomas are classified as a metaplastic form of endometrial cancers, leiomyosarcomas (LMSs) are the most frequently observed subgroup..$^{[3]}$ Although LMSs are mostly diagnosed at an early stage, their prognosis is poor. The number of mitosis, nuclear atypia and the presence of necrosis in the tumor cell are used as histopathological diagnostic criteria.

The second most frequently observed uterine endometrial stromal sarcomas (ESSs) of the mesenchymal origin are subdivided into low-grade ESS, high-grade ESS and undifferentiated ESS, depending on the differentiation rates of the cells. ${ }^{[4]}$ The prognosis of low-grade ESS is better than the other two types.

Mixed sarcomas contain a mixture of malignant mesenchymal component and epithelial component. Carcinosarcomas, also called malignant mixed Mullerian tumors 
(MMMTs), consist of malignant epithelial and mesenchymal stromal cells and lead a highly aggressive course. Mesenchymal components can be homologous or heterologous, which has no clinical significance. ${ }^{[5]}$ If the epithelial component of mixed sarcoma is benign, it takes the name adenosarcoma and usually grows as a polypoid mass into the uterine cavity.

Pelvic radiation history, tamoxifen use and long-term estrogen use have been identified as risk factors for black race sarcomas. The risk was low with the use of cigarettes and oral combined contraceptives.

Patients usually present with the compression symptoms of the tumor, such as abnormal uterine bleeding, abdominal pain and swelling in the abdomen. Today, there is no laboratory test or imaging method that precisely diagnoses preoperative sarcoma. Ultrasonography and magnetic resonance imaging (MR) can provide information about localization of the disease and distant metastases. The success of endometrial sampling in diagnosing uterine sarcoma is lower than in uterine epithelial malignancies. The final diagnosis is made histopathologically. The most important prognostic factor is the stage of the tumor. They are staged according to the FIGO (International Federation of Gynecology and Obstetrics) 2009 system. Because of their rarity, there is no consensus in their treatment. Total abdominal hysterectomy and bilateral salpingo-ophorectomy is the standard surgical approach. Post-surgical chemotherapy and radiotherapy applications are controversial.

The purpose of this retrospective study is to evaluate the typical features of patients diagnosed with uterine sarcoma over a 10-year period and the approach of our clinic to these patients.

\section{MATERIALS AND METHODS}

In this study, 55 patients whose histopathological diagnosis was made as uterine sarcoma between 2004 and 2014 in the gynecology department of our clinic were evaluated retrospectively. Ethics committee approval was obtained before conducting this study. The age, parity, menopausal status, presence of chronic disease, clinical symptoms, tumor type, probe curettage and frozen pathological examination results, type of operation performed, tumor size, presence of atypia and necrosis, radiotherapy and chemotherapy, pathological comorbidities, disease-free survival and overall survival data were evaluated. Recurrent cases of sarcoma cases were excluded from the study. The surgical specimens obtained were evaluated by the pathology department of our hospital and staged according to the FIGO 2009 system. The information about follow-up times and the presence of recurrence was acquired by calling the patient from the records and by phone. $\mathrm{Pa}$ tients' death dates were retrieved from the Ministry of Health patient death reports logged in the hospital database. Disease-free survival was calculated as the time until the symptoms of sarcoma recurrence or metastasis after treatment, and overall survival was the time from the day of diagnosis of sarcoma to the moment of death. Serum Ca- 125 levels above the reference range $(35 \mathrm{IU} / \mathrm{ml})$ were considered pathologic.

SPSS (Statistical Package for Social Sciences Inc, Chicago, IL, the USA for Windows) I5.0 program was used for statistical analysis. Average and standard deviations of the analyzed parameters were calculated.

\section{RESULTS}

A total of 4468 hysterectomies and 263 myomectomies had been performed between 01.01.2004-01.01.2014, to treat 55 cases with uterine sarcomas, including carcinosarcomas $(n=31: 56.36 \%)$, leiomyosarcoma $(n=15: 27.3 \%)$, endometrial stromal sarcoma $(n=6: 10.9 \%)$, and adenosarcomas $(n=3: 5.5 \%)$. The median age at the time of diagnosis was $60.75 \pm 12.74$ (minimum: 33 , maximum: 86 ) years, and 43 patients $(78.2 \%)$ were in the postmenopausal period. Clinical characteristics of patients are shown in Table I, and methods of diagnosis, stage of the tumors and treatment types in Table 2. In our study, endometrial sampling was performed for $35(63.6 \%)$ of 40 patients with abnormal uterine bleeding. Preoperatively, sarcoma was detected in 26 cases (47.3\%). Endometrial sampling could not be performed in five patients due to cervical stenosis. Endometrial sampling was performed in five of 15 LMS patients. Sarcoma was detected in one patient. Endometrial sampling was performed in 25 of 30 MMMT cases and MMMT was detected in 23 of them. Repetition of the procedure was recommended by the pathologist due to atypical cell monitoring in two cases.

Endometrial sampling was performed in two of three adenosarcoma cases, and adenosarcoma was observed in one case and atypical glandular cells were observed in the other. Endometrial sampling was performed in three of the six ESS cases, while the malignant mesenchymal tumor was detected in one case, and carcinoma in another case. Any signs of malignancy were not found in a surgical specimen, which was reported as normal.

In 17 cases (30.9\%), sarcoma was diagnosed intraoperatively by pathological examination of frozen section material. Specimens obtained from nine LMS patients were sent for a frozen section examination, and five of them were diagnosed with sarcoma, while four specimens could not be evaluated clearly by the pathologist. It was reported that there was no typical sarcoma appearance, the potential for malignancy was uncertain, and the exact diagnosis would be made after examination of paraffin-embedded specimens. Specimens of seven MMMT patients were sent for a frozen section pathological examination, and the results of all of them were compatible with the diagnosis of MMMT. Frozen section materials of four ESS patients were sent for pathological examination, and all of them were compatible with sarcoma. All of the specimens obtained from adenosarcoma cases were sent to frozen pathological examination and in the case in which atypical glandular cell 
Table I. Clinical characteristics of the patients

\begin{tabular}{|c|c|c|c|c|c|}
\hline & All cases with sarcoma $(n=55)$ & MMMT $(n=31)$ & LMS $(n=15)$ & ESS $(n=6)$ & AS $(n=3)$ \\
\hline Mean age, mean $\pm S D$ & $60.75 \pm 12.74$ & $65.12 \pm 12.82$ & $52 \pm 8.9$ & $60.83 \pm 13.08$ & $59 \pm 7.55$ \\
\hline \multicolumn{6}{|l|}{ Age at diagnosis } \\
\hline$<40$ & 3 & 2 & 1 & - & - \\
\hline $4 I-50$ & 9 & 1 & 6 & 2 & - \\
\hline $51-60$ & 17 & 8 & 6 & 1 & 2 \\
\hline$>60$ & 26 & 20 & 2 & 3 & 1 \\
\hline \multicolumn{6}{|l|}{ Symptoms, n (\%) } \\
\hline Abnormal bleeding & $40(72.7)$ & $27(87.1)$ & $7(46.7)$ & $3(50.0)$ & $3(100)$ \\
\hline Abdominal pain & $17(30.9)$ & $8(25.8)$ & $5(33.3)$ & $4(66.7)$ & - \\
\hline Abdominal swelling & $5(9.1)$ & II (3.2) & $4(26.7)$ & - & - \\
\hline \multicolumn{6}{|l|}{ Parity, n (\%) } \\
\hline Uni-multipar & $49(89.1)$ & $27(87.1)$ & $13(86.7)$ & $6(100)$ & $3(100)$ \\
\hline Nullipar & $3(5.5)$ & $2(6.5)$ & I (7.I) & - & - \\
\hline Infertility & $3(5.5)$ & $2(6.5)$ & I (7.I) & - & - \\
\hline Postmenopausal & $43(78.2)$ & $28(90.3)$ & $7(50)$ & $5(83.3)$ & $3(100)$ \\
\hline Smoking & II (20) & $6(19.4)$ & $3(21.4)$ & $2(33.3)$ & - \\
\hline DM & $14(25.5)$ & $7(22.6)$ & $3(2 \mid .4)$ & $2(33.3)$ & $2(66.7)$ \\
\hline HT & $22(40)$ & $15(48.4)$ & $3(21.4)$ & $3(50)$ & I (33.3) \\
\hline
\end{tabular}

MMMT: Malignant mixed Mullerian tumor; LMS: Leiomyosarcoma; ESS: Endometrial stromal sarcoma; AS: Adenosarcoma; DM: Diabetes mellitus; HT: Hypertension; SD: Standard deviation.

was detected as a result of endometrial sampling, frozen pathological examination of the case with adenocarcinoma as a result of endometrial sampling was reported as adenofibroma. It was reported by the pathologist that the frozen pathological examination of the materials sent without endometrial sampling was compatible with the endometrial polyp, that the invasive tumor area was not observed in the sampled area and that a histopathological examination of a large number of samples should be performed due to the large size of the polyp. Of the remaining 12 patients, II were diagnosed after histopathologic examination of hysterectomy specimens and one patient was diagnosed in the postoperative period, as a result of the examination of the myomectomy material by the pathologist

Serum Ca- 125 level was increased in 10 (18.2\%) and within normal limits in 26 patients (47.3\%), and no data were found in 19 patients (34.5\%). Serum Ca- 125 level was increased in two of six LMS and eight of 26 MMMT patients.

Two patients $(3.6 \%)$ could not be operated and surgical staging could not be performed due to advanced-stage disease and serious medical comorbidities (chronic kidney failure and advanced heart failure). Of the 53 patients who underwent surgery, $3 \mathrm{I}(58.5 \%)$ were operated by the gynecologist-oncologist, and 22 patients $(41.5 \%)$ by the general gynecologist. At the time of diagnosis, distant metastases were detected in the liver in two and lung in one patient, and the final diagnosis of all three was MMMT.

Primary treatment was surgical for all patients; neoadjuvant chemotherapy and radiotherapy were not applied. Except for one case, all cases underwent a total abdominal hysterectomy and bilateral salpingo- oophorectomy as a surgical procedure. Total abdominal hysterectomy and bilateral salpingo-ophorectomy were performed on the postoperative 13th day after the pathology report of the patient who underwent abdominal myomectomy with an initial diagnosis of leiomyoma were available. Abdominal fluid sampling was performed in 30 , omentectomy in 26 , appendectomy in 17 , pelvic lymph node dissection in 28 , and paraaortic lymph node dissection in 12 patients. Lymph node positivity was only observed in MMMT cases, and no positivity was found in other types of sarcoma. Nine $(42.9 \%)$ of 21 pelvic lymph node dissections were performed in MMMT cases, and histopathologic examination of four $(57.1 \%)$ of seven paraaortic lymph node were positive for MMMT.

In four cases, partial colon resection was performed, together with a general surgeon, due to tumor infiltration, and then a colostomy was opened. A second surgical procedure was not applied to 10 patients who had undergone total abdominal hysterectomy and bilateral salpingo-oophorectomy due to abnormal uterine bleeding, and whose sarcoma was diagnosed by histopathological evaluation in the postoperative period.

Adjuvant chemotherapy was applied to 16 patients, adjuvant radiotherapy to six patients, adjuvant chemotherapy and radiotherapy to $2 \mathrm{I}$ patients.

Certain rates of necrosis and atypia were observed in all I5 LMS patients. While the number of mitosis was more than 15 in 12 patients, it was less than 15 in three patients. The mean LMS tumor diameter was $12.7 \mathrm{~cm}(4-38 \mathrm{~cm})$. LMS was found in the corpus in II, in the fundus in 3, and in the isthmic region in one patient. MMMT mean tumor 
Table 2. Methods of the diagnosis, stage of the tumors, and treatment modalities

\begin{tabular}{|c|c|c|c|c|c|}
\hline & $\begin{array}{l}\text { All cases with sarcoma } \\
\qquad(n=55)\end{array}$ & $\begin{array}{l}\text { MMMT } \\
(n=31)\end{array}$ & $\begin{array}{l}\text { LMS } \\
(n=15)\end{array}$ & $\begin{array}{l}\text { ESS } \\
(n=6)\end{array}$ & $\begin{array}{c}\text { AS } \\
(n=3)\end{array}$ \\
\hline \multicolumn{6}{|l|}{ Methods of diagnosis, n (\%) } \\
\hline Endometral sampling & $26(47.3)$ & $23(74.2)$ & I (6.7) & I (I6.7) & I (33.3) \\
\hline Histopathologic examination & $17(30.9)$ & $7(22.6)$ & $5(33.3)$ & $4(66.7)$ & I (33.3) \\
\hline \multicolumn{6}{|l|}{ of the frozen section material } \\
\hline Hysterectomy & II (20) & I (3.2) & $8(53.3)$ & I (I6.7) & I (33.3) \\
\hline Myomectomy & $\mathrm{I}(\mathrm{I} .8)$ & - & I (6.7) & - & - \\
\hline \multicolumn{6}{|l|}{ Stages } \\
\hline Stage I & $36(65.5)$ & $15(48.4)$ & $14(93.3)$ & $5(83.3)$ & $2(66.7)$ \\
\hline Stage 2 & $\mathrm{I}(\mathrm{I} .8)$ & - & - & - & I (33.3) \\
\hline Stage 3 & $7(12.7)$ & $6(19.4)$ & - & I (I6.7) & - \\
\hline Stage 4 & $9(16.4)$ & $8(25.8)$ & I (6.7) & - & - \\
\hline \multicolumn{6}{|l|}{ Tumor size } \\
\hline$<5 \mathrm{~cm}$ & $22(4 \mid .5)$ & $14(48.3)$ & $4(26.7)$ & $2(33.3)$ & $2(66.7)$ \\
\hline $5-10 \mathrm{~cm}$ & $19(35.8)$ & $12(41.4)$ & $4(26.7)$ & $2(33.3)$ & I (33.3) \\
\hline $10 \mathrm{~cm}$ & $14(26.4)$ & $5(46.7)$ & $7(46.7)$ & $2(33.3)$ & - \\
\hline \multicolumn{6}{|l|}{ Treatment } \\
\hline \multicolumn{6}{|l|}{ Surgical technique } \\
\hline $\mathrm{TAH}+\mathrm{BSO}$ & $52(94.5)$ & $29(93.5)$ & $14(93.3)$ & $6(100)$ & $3(100)$ \\
\hline Myomectomy & I (I.8I) & - & I (6.66) & - & - \\
\hline \multicolumn{6}{|l|}{ Lymphadenectomy } \\
\hline Pelvic & $28(50.9)$ & $21(67.7)$ & $2(13.3)$ & $4(66.7)$ & I (33.3) \\
\hline Paraaortic & $12(21.8)$ & $7(22.6)$ & $2(13.3)$ & $2(33.3)$ & I (33.3) \\
\hline Omentectomy & $26(47.3)$ & $18(59.0)$ & $3(20.0)$ & $4(66.7)$ & I (33.3) \\
\hline Appendectomy & $17(30.9)$ & $12(38.7)$ & I (6.7) & $3(50.0)$ & I (33.3) \\
\hline Surgery+RT & $6(10.9)$ & $6(19.4)$ & - & - & - \\
\hline Surgery+CT & $16(30.0)$ & $7(22.6)$ & $4(26.7)$ & $3(50.0)$ & $2(66.7)$ \\
\hline Surgery+RT+CT & $21(38.2)$ & $12(38.7)$ & $8(53.3)$ & I (I6.7) & - \\
\hline
\end{tabular}

MMMT: Malignant mixed Mullerian tumor; LMS: Leiomyosarcoma; ESS: Endometrial stromal sarcoma; AS: Adenosarcoma; DM: Diabetes Mellitus; HT: Hypertension; TAH: Total Abdominal Hysterectomy; BSO: Bilateral Salphingo-oophorectomy; RT: Radiotherapy; CT: Chemotherapy.

diameter was $5.8 \mathrm{~cm}(0.7-18 \mathrm{~cm})$, adenosarcoma mean tumor diameter was $4.2 \mathrm{~cm}(3-6 \mathrm{~cm})$, and ESS mean tumor diameter was $8.3 \mathrm{~cm}(0.5-16 \mathrm{~cm})$.

Stage- 3 and stage- 4 patients were excluded from the calculation and disease-free survival times of 36 patients were determined. The mean disease-free survival time was 30.2 months (2-55 months) for MMMT, 31.78 months (5-68 months) for LMS, 58.5 months (8-135 months) for ESS and 51.66 months (24-77 months) for adenosarcoma. The average survival time was calculated as 46.96 months (I-87 months) for MMMT, 49.61 months (II-II5 months) for LMS, 84.8 months (65-135 months) for ESS, 68.7 months (63-77 months) for adenosarcoma. Until January 2019, when the data were collected, 37 patients $(67.3 \%)$ died.

\section{DISCUSSION}

Uterine sarcomas are rarely seen and constitute about 3 to $9 \%$ of all uterine malignancies. Since they tend to metastasize and recur in the early period, their prognosis is worse than other uterine malignancies. ${ }^{[6,7]}$
In this retrospective study, the typical features of patients diagnosed with uterine sarcoma over a 10 -year period and the approach of our clinic to these patients were evaluated. The majority $(78.2 \%)$ of patients were diagnosed over the age of 50 , while only three patients $(5.5 \%)$ were diagnosed under the age of 40 . Although the clinical symptoms of uterine sarcomas are not typical, the patients usually present with symptoms of tumor compression, such as postmenopausal bleeding, abdominal pain and abdominal swelling, or more rarely rectal bleeding, hematuria and symptoms related to organ metastases. In this study, 40 (72.7\%) patients were admitted with abnormal vaginal bleeding, 22 (39.8\%) cases with abdominal pain and abdominal swelling. Giuntoli et al. ${ }^{[8]}$ reported vaginal bleeding (56\%), palpable pelvic mass and pain (54\%), as the most frequent presenting abnormal symptoms in patients with LMS. While Chang et al. ${ }^{[9]}$ reported that patients with ESS most frequently (75\%) presented with abnormal vaginal bleeding and pelvic pain.

Today, there is no laboratory test or imaging method that precisely diagnoses preoperative sarcoma. Ultrasonogra- 
phy, which is the most commonly used imaging method, is inadequate in distinguishing leiomyoma from leiomyosarcoma. In sarcomas, the hematogenous spread is frequently observed and lung metastasis is most common. Therefore, if a diagnosis of sarcoma is made in the preoperative period or if sarcoma is suspected, it is necessary to scan the lungs with thorax computed tomography (CT). In addition, abdominopelvic MR or CT can be used to evaluate tumor localization and other possible metastases

Menczer et al. ${ }^{[10]}$ emphasized that serum $\mathrm{Ca}-\mathrm{I} 25$ is a nonspecific marker and relevant data are insufficient to be a reliable predictor for sarcomas. In our study, serum CaI 25 level was measured in 36 patients preoperatively and only 10 patients (I8.2\%) had high (>35 IU/MI) serum Ca125 levels. Two patients with high serum $\mathrm{Ca}-\mathrm{I} 25$ levels were diagnosed as having LMS, eight cases as MMMT and all were diagnosed at an advanced stage.

Patients with MMMT can be diagnosed in the preoperative period with a histopathological examination of the mass extending from the cervix or endometrial curettage specimen. However, since LMS mostly develops into the myometrium, preoperative diagnosis cannot be made. In their review article Bansal et al. ${ }^{[1]}$ showed that the predictive value of endometrial sampling in diagnosing uterine sarcoma was significantly lower than that of uterine epithelial malignancies (64\% vs. $81 \%$ ). Skorstad et al. ${ }^{[12]}$ performed preoperative endometrial sampling in 142 LMS patients and showed histopathological sarcoma in 55 patients (38.7\%). They also stated that endometrial sampling has low sensitivity in the diagnosis of LMS. In our study, in 35 of 40 patients with abnormal uterine bleeding endometrial sampling was performed, and 26 patients were diagnosed with sarcoma in the preoperative period. In five patients, endometrial sampling was not possible due to severe cervical stenosis and patients were operated for clinical suspicion without sampling. The diagnostic effectiveness of endometrial sampling in diagnosis varies significantly between sarcoma types.

In this study, in 25 patients with MMMT, endometrial sampling was performed and 23 patients had positive results, while two patients were reported as suspected cases. This result suggests that endometrial sampling is very effective in the diagnosis of MMMT. Only one of the five LMS patients with endometrial sampling yielded positive results. It was found that the outcome of one of the three ESS patients with endometrial sampling was reported as benign. These findings show that the success of endometrial sampling in preoperative diagnosis should be questioned in sarcomas other than MMMT. However, it should be performed due to the risk of malignancy in patients with premenopausal and especially postmenopausal abnormal uterine bleeding.

The use of intraoperative pathological examination of frozen section samples in gynecological pathologies is an important guiding tool in providing the possible diagnosis, determining the surgical staging of tumors and choosing the surgical procedure. Pathological examination of frozen section materials plays an important role, especially in dem- onstrating the degree and depth of myometrial invasion of uterine adenocarcinomas and accordingly directing the primary surgical treatment. ${ }^{[13]}$ Histopathological examination of the specimens sent for frozen section may be limited to sampling a small area of tumor elements, or there may be artifacts that can disrupt tissue architecture and morphology during frozen pathological examination, which may result in false-negative results. ${ }^{[14]}$ In cases where malignancy is not suspected in the preoperative period, but there is a suspicion of malignancy in the intraoperative period, the intraoperative frozen pathological examination can be used. Bostancl et al. ${ }^{[15]}$ found the consistency rate of frozen pathological examination in sarcomas as $55 \%$ in their 29 -case study. In our study, while the results of the frozen section examination of seven MMMT and four ESS patients were reported as suspicious for intraoperative malignancy, the results of five of nine LMS patients sent for a frozen pathological examination were reported as sarcoma.

In four cases, a clear result could not be reported by the pathologist, and the result of one of three adenosarcoma patients who were sent for a frozen pathological examination was reported as sarcoma, the other as an endometrial polyp and the third patient as adenofibroma. With these results, we believe that the reliability of frozen pathological examinations should be questioned as for the diagnosis of uterine sarcomas.

The tumor stage alone is the most important prognostic factor. In 2009, FIGO developed the new staging system for uterine sarcomas, which consists of two parts. While LMS and ESS are staged in the same section, adenosarcomas are staged in the other section. The endometrial carcinoma staging system is used for MMMT. ${ }^{[16]}$

Preoperative differentiation of LMS from leiomyomas is difficult due to the similar clinical signs and symptoms and their radiological appearance. Sarcoma should be suspected in fast-growing myomas, especially during the postmenopausal period. Although LMSs present in the early stages, their prognosis is poor.

In their study, Pellanda et al. ${ }^{[17]}$ found 80 of II 0 LMS patients in stage-I and 5-year survival as $59 \%$. In our study, I 4 (93.3\%) of I5 LMS cases were detected in stage-I and the average survival time was found to be 49.6 months.

Adenosarcomas consisting of benign epithelial and malignant mesenchymal components are most commonly seen in the uterus, and secondly, in the ovaries. ${ }^{[18,19]}$ They are mostly observed in the postmenopausal period and present symptoms with abnormal vaginal bleeding. They are often diagnosed at an early stage. ${ }^{[20,21]}$ In a retrospective study, Clement et al. ${ }^{[18]}$ reported a 5-year average survival rate as $60.2 \%$. It was observed that three adenosarcoma patients in our study applied to us with postmenopausal bleeding and were diagnosed at an early stage. The average survival time was determined as 68.66 months, which was compatible with the literature.

Low- grade ESS, which is the most frequently observed subtype of ESS, is most often seen in $5^{\text {th }}$ decade of life. 
ESS presents with abnormal uterine bleeding and pelvic pain, and its prognosis is better than other subtypes. ${ }^{[22]}$ Agarwal et al. ${ }^{[23]}$ reported the 5-year survival rate of 28 patients diagnosed with low- grade ESS as $89.1 \%$. In our study, three of four patients diagnosed with low -grade ESS had abnormal vaginal bleeding at the time of admission and two of them had abdominal pain, and their mean survival time was 85 months.

UES is frequently seen over 60 years of age and presents with postmenopausal bleeding, and about $60 \%$ of the cases are detected in an advanced stage. ${ }^{[24]}$ In our study, the mean age of two patients diagnosed with UES was 75.5 years, and it was observed that both patients presented with abdominal pain. The patient, who was detected in stage-Ib, died on the II th postoperative day despite tissue debridement and multiagent antibiotic use for the treatment of necrotizing fasciitis developed five days after the operation. The other patient was detected at stage 3 UES and died in the postoperative 18th month.

The average age of high-grade ESS patients at diagnosis is 50 , and the prognosis of these sarcomas is between the other two types. They have a higher recurrence rate at an earlier stage of the disease when compared with lowgrade ESS. ${ }^{[25]}$ In their study, Seagle et al. ${ }^{[26]}$ found the average 5-year survival time to be 19.9 months for high-grade ESS. High-grade ESS was not encountered in our study.

Carcinosarcomas, also called MMMT, are rare tumors and more aggressive than endometrial carcinomas. MMMT is diagnosed, especially in the $60 \mathrm{~s}$ and patients often present with postmenopausal bleeding. ${ }^{[27]}$ According to the appearance of sarcomatous components, they are divided into two histological subgroups. While homologous type cells are specific to the uterus, the heterogeneous type includes non-uterine cells, such as rhabdomyosarcoma, chondrosarcoma, osteosarcoma, and liposarcoma. Since MMMT started to be defined as metaplastic carcinoma, it has been included in the mixed tumors of the uterus in the histological classification of the World Health Organization (2003) and has been staged according to the FIGO 2009 endometrial carcinoma staging system. ${ }^{[16,28-30]}$

Surgical staging is the most important prognostic factor. Due to their aggressive course, adjuvant chemotherapy is recommended after surgery, and mostly radiotherapy is also added to the treatment. ${ }^{[29]}$ Their prognosis is poor and the 5-year average survival rate has been reported as approximately $30 \% .{ }^{[32,33]}$ In our study, it was found that the average age of 31 patients diagnosed with MMMT was 65.1 years and the majority of them (88.0\%) applied with abnormal vaginal bleeding. The average disease-free survival time was 30.2 months (2-55 months), and the average survival time was 47.0 months ( $1-87$ months).

Optimal treatment is still debatable as uterine sarcomas are rarely seen entities. Although surgery is the main treatment, total abdominal hysterectomy, together with bilateral salpingo-ophorectomy, is the standard approach, while the effects of bilateral salpingo-ophorectomy on sur- vival are not clear. ${ }^{[34]}$ Ovarian preservation may be considered in early-stage premenopausal LMS patients. ${ }^{[8]}$

In our study, all patients, except a patient who underwent myomectomy, underwent a total abdominal hysterectomy and bilateral salpingo-oophorectomy as a surgical procedure. The addition of lymphadenectomy to the surgery is controversial. In our study, it was found that lymph node positivity was observed only in MMMT patients. In nine $(42.9 \%)$ of 21 MMMT patients who had pelvic lymph node dissection, and in four (57.1\%) of seven patients who underwent paraaortic, lymph node dissection lymph node positivity was observed. In uterine sarcomas, adjuvant radiotherapy and chemotherapy can be applied in advanced stages, in cases of metastasis and recurrence. However, their effectiveness is not clear. ${ }^{[35-38]}$ In our study, adjuvant chemotherapy was applied to 16 patients, adjuvant radiotherapy to six patients, adjuvant chemotherapy and radiotherapy to 21 patients.

Uterine sarcomas are rare and highly aggressive tumors. They are generally seen at advanced ages, and patients often present with abnormal vaginal bleeding. There is no laboratory test or imaging method to establish the diagnosis of preoperative sarcoma. It should be kept in mind that endometrial sampling may help the establishment of diagnosis and that negative results cannot rule out the diagnosis of sarcoma. It should be remembered that the results of intraoperative pathological examination of frozen section samples may be negative. The final diagnosis is made histopathologically. In its management, primary treatment is surgery, and the addition of lymph node dissection is controversial. Since the effects of bilateral salpingo-ophorectomy on survival are not clear, preservation of ovaries may be considered in young patients. Another controversial issue is adjuvant chemotherapy and radiotherapy. Each histological type should be handled separately.

Ethics Committee Approval

Approved by the local ethics committee (27.03.20192019/5I4/I50/19).

Informed Consent

Retrospective study.

Peer-review

Internally peer-reviewed.

Authorship Contributions

Concept: G.Y., E.C.G., G.B., E.M., A.K.; Design: G.Y., E.C.G., G.B., E.M., A.K.; Supervision: G.Y., E.C.G., G.B., E.M., A.K.; Fundings: G.Y., G.B.; Materials: G.Y., A.K.; Data: G.Y., E.C.G.; Analysis: G.Y., E.M.; Literature search: G.Y., E.C.G.; Writing: G.Y., E.M. G.B.; Critical revision: G.Y., A.K., G.B.

Conflict of Interest

None declared.

\section{REFERENCES}

1. Major FJ, Blessing JA, Silverberg SG, Morrow CP, Creasman WT, Currie JL, et al. Prognostic factors in early-stage uterine sarcoma. 
Cancer 1993;71:1702-9. [CrossRef]

2. Abeler VM, Røyne O, Thoresen S, Danielsen HE, Nesland JM, Kristensen GB. Uterine sarcomas in Norway. A histopathological and prognostic survey of a total population from 1970 to 2000 including 419 patients. Histopathology 2009;54:355-64. [CrossRef]

3. D'Angelo E, Prat J. Uterine sarcomas: a review. Gynecol Oncol 2010;116:131-9. [CrossRef]

4. Nucci MR. Practical issues related to uterine pathology: endometrial stromal tumors. Mod Pathol 2016;29:S92-103. [CrossRef]

5. McCluggage WG. Uterine carcinosarcomas (malignant mixed Mullerian tumors) are metaplastic carcinomas. Int J Gynecol Cancer 2002;12:687-90. [CrossRef]

6. Fletcher CD. The evolving classification of soft tissue tumours-an update based on the new 2013 WHO classification. Histopathology 2014;64:2-11. [CrossRef]

7. Tropé CG, Abeler VM, Kristensen GB. Diagnosis and treatment of sarcoma of the uterus. A review. Acta Oncol 2012;51:694-705. [CrossRef]

8. Giuntoli RL 2nd, Metzinger DS, DiMarco CS, Cha SS, Sloan JA, Keeney GL, et al. Retrospective review of 208 patients with leiomyosarcoma of the uterus: prognostic indicators, surgical management, and adjuvant therapy. Gynecol Oncol 2003;89:460-9. [CrossRef]

9. Chang KL, Crabtree GS, Lim-Tan SK, Kempson RL, Hendrickson MR. Primary uterine endometrial stromal neoplasms. A clinicopathologic study of 117 cases. Am J Surg Pathol 1990;14:415-38. [CrossRef]

10. Menczer J, Schreiber L, Berger E, Ben-Shem E, Golan A, Levy T. CA125 expression in the tissue of uterine leiomyosarcoma. Isr Med Assoc J 2014;16:697-9.

11. Bansal N, Herzog TJ, Burke W, Cohen CJ, Wright JD. The utility of preoperative endometrial sampling for the detection of uterine sarcomas. Gynecol Oncol 2008;110:43-8. [CrossRef]

12. Skorstad M, Kent A, Lieng M. Preoperative evaluation in women with uterine leiomyosarcoma. A nationwide cohort study. Acta Obstet Gynecol Scand 2016;95:1228-34. [CrossRef]

13. Quinlivan JA, Petersen RW, Nicklin JL. Accuracy of frozen section for the operative management of endometrial cancer. BJOG 2001;108:798-803. [CrossRef]

14. El-Bahrawy M, Ganesan R. Frozen section in gynaecology: uses and limitations. Arch Gynecol Obstet 2014;289:1165-70. [CrossRef]

15. Bostancı E, Ayas S, Gürbüz T, Gürbüz A, Karateke A. Retrospective analysis of 29 cases with uterine sarcoma: A single center experience. Dicle Med J 2015;42:175-80. [CrossRef]

16. Prat J. FIGO staging for uterine sarcomas. Int J Gynaecol Obstet 2009;104:177-8. [CrossRef]

17. Pellanda AF, De Bari B, Deniaud-Alexandre E, Krengli M, Van Houtte $\mathrm{P}$, Richetti A, et al. Outcome and prognostic factors in 110 consecutive patients with primary uterine leiomyosarcoma: A Rare Cancer Network study. Chin J Cancer Res 2017;29:521-32. [CrossRef]

18. Clement PB, Scully RE. Mullerian adenosarcoma of the uterus: a clinicopathologic analysis of 100 cases with a review of the literature. Hum Pathol 1990;21:363-81. [CrossRef]

19. Carleton C, Houghton OP, McCluggage WG. Juvenile granulosa cell tumor arising in ovarian adenosarcoma: an unusual form of sarcomatous overgrowth. Hum Pathol 2015;46:614-9. [CrossRef]

20. Bernard B, Clarke BA, Malowany JI, McAlpine J, Lee CH, Atenafu EG, et al. Uterine adenosarcomas: a dual-institution update on staging, prognosis and survival. Gynecol Oncol 2013;131:634-9. [CrossRef]

21. Verschraegen CF, Vasuratna A, Edwards C, Freedman R, Kudelka AP, Tornos C, et al. Clinicopathologic analysis of Mullerian adenosarcoma: the M.D. Anderson Cancer Center experience. Oncol Rep 1998;5:939-44. [CrossRef]

22. D’Angelo E, Espinosa I, Ali R, Gilks CB, van de Rijn M, Lee CH, et al. Uterine leiomyosarcomas: tumor size, mitotic index, and biomark- ers Ki67, and Bcl-2 identify two groups with different prognosis. Gynecol Oncol 2011;121:328-33. [CrossRef]

23. Agarwal R, Rajanbabu A, Nair IR, Satish C, Jose G, Unikrishnan UG. Endometrial stromal sarcoma-A retropsective analysis of factors affecting recurrence. Eur J Obstet Gynecol Reprod Biol 2017;216:92-7. [CrossRef]

24. Tanner EJ, Garg K, Leitao MM Jr, Soslow RA, Hensley ML. High grade undifferentiated uterine sarcoma: surgery, treatment, and survival outcomes. Gynecol Oncol 2012;127:27-31. [CrossRef]

25. Lee CH, Mariño-Enriquez A, Ou W, Zhu M, Ali RH, Chiang S, et al. The clinicopathologic features of YWHAE-FAM22 endometrial stromal sarcomas: a histologically high-grade and clinically aggressive tumor. Am J Surg Pathol 2012;36:641-53. [CrossRef]

26. Seagle BL, Shilpi A, Buchanan S, Goodman C, Shahabi S. Low-grade and high-grade endometrial stromal sarcoma: A National Cancer Database study. Gynecol Oncol 2017;146:254-62. [CrossRef]

27. Ramondetta LM, Burke TW, Jhingran A, Schmandt R, Bevers MW, Wolf JK, et al. A phase II trial of cisplatin, ifosfamide, and mesna in patients with advanced or recurrent uterine malignant mixed müllerian tumors with evaluation of potential molecular targets. Gynecol Oncol 2003;90:529-36. [CrossRef]

28. Ferguson SE, Tornos C, Hummer A, Barakat RR, Soslow RA. Prognostic features of surgical stage I uterine carcinosarcoma. Am J Surg Pathol 2007;31:1653-61. [CrossRef]

29. Yamada SD, Burger RA, Brewster WR, Anton D, Kohler MF, Monk BJ. Pathologic variables and adjuvant therapy as predictors of recurrence and survival for patients with surgically evaluated carcinosarcoma of the uterus. Cancer 2000;88:2782-6. [CrossRef]

30. Tavassoli FA, Devilee P, editors. Pathology and Genetics: Tumours of the Breast and Female Genital Organs. World Health Organization Classification of Tumours. Lyon: IARC; 2003.

31. Homesley HD, Filiaci V, Markman M, Bitterman P, Eaton L, Kilgore LC, et al. Phase III trial of ifosfamide with or without paclitaxel in advanced uterine carcinosarcoma: a Gynecologic Oncology Group Study. J Clin Oncol 2007;25:526-31. [CrossRef]

32. Silverberg SG, Major FJ, Blessing JA, Fetter B, Askin FB, Liao SY, et al. Carcinosarcoma (malignant mixed mesodermal tumor) of the uterus. A Gynecologic Oncology Group pathologic study of 203 cases. Int J Gynecol Pathol 1990;9:1-19. [CrossRef]

33. George E, Lillemoe TJ, Twiggs LB, Perrone T. Malignant mixed müllerian tumor versus high-grade endometrial carcinoma and aggressive variants of endometrial carcinoma: a comparative analysis of survival. Int J Gynecol Pathol 1995;14:39-44. [CrossRef]

34. Kapp DS, Shin JY, Chan JK. Prognostic factors and survival in 1396 patients with uterine leiomyosarcomas: emphasis on impact of lymphadenectomy and oophorectomy. Cancer 2008;112:820-30.

35. Bogani G, Fucà G, Maltese G, Ditto A, Martinelli F, Signorelli M, et al. Efficacy of adjuvant chemotherapy in early stage uterine leiomyosarcoma: A systematic review and meta-analysis. Gynecol Oncol 2016;143:443-7. [CrossRef]

36. Benson C, Miah AB. Uterine sarcoma-current perspectives. Int J Womens Health 2017;9:597-606. [CrossRef]

37. Gronchi A, Frustaci S, Mercuri M, Martin J, Lopez-Pousa A, Verderio $\mathrm{P}$, et al. Short, full-dose adjuvant chemotherapy in high-risk adult soft tissue sarcomas: a randomized clinical trial from the Italian Sarcoma Group and the Spanish Sarcoma Group. J Clin Oncol 2012;30:850-6. [CrossRef]

38. Seddon B, Strauss SJ, Whelan J, Leahy M, Woll PJ, Cowie F, et al. Gemcitabine and docetaxel versus doxorubicin as first-line treatment in previously untreated advanced unresectable or metastatic softtissue sarcomas (GeDDiS): a randomised controlled phase 3 trial. Lancet Oncol 2017;18:1397-410. [CrossRef] 


\section{Uterin Sarkomlar: Tek Merkezin 10 Yıllık Deneyimi}

Amaç: Bu çalışmadaki amaç, uterin sarkom tanısı alan hastaların sosyodemografik özelliklerini ve bu hastalara klinik yaklaşımı değerlendirmektir.

Gereç ve Yöntem: Bu çalışmada Kadın Hastalıkları ve Doğum Kliniğimizde I Ocak 2004-I Ocak 2014 tarihleri arasında uterin sarkom tanısı alan 55 hasta geriye dönük olarak irdelendi. Hastaların tıbbi dosyalarına ulaşılarak sosyodemografik veriler, hastalığın tanı ve tedavi süreçlerinde uygulanan yöntemler araştırıldı. Hastalar telefonla aranarak hastalığın progresyonu ve rekürrens ile ilgili bilgilerine ulaşıldı. Sağlık bakanlığı hasta ölüm bildirim raporlarına ulaşılarak hasta ölüm tarihleri belirlendi ve bulgular istatiksel olarak analiz edildi.

Bulgular: Otuz bir karsinosarkom (\%56.4), I5 leiomyosarkom (\%27.3), altı endometrial stromal sarkom (\%I I), üç adenosarkom (\%5.5) olmak üzere toplam 55 uterin sarkom tanılı hasta değerlendirmeye alındı. Ortalama yaş 60.75 12.74 (yaş aralığı 33-86) idi. Kırk üç hasta (\%78.2) postmenopozal dönemde idi. Yirmi altı hasta (\%47.3) endometrial örnekleme, I7 hasta (\%3I) frozen patolojik inceleme, II hasta abdominal histerektomi (\%20) ve bir hasta abdominal miyomektomi (\%।.8) tanısı aldı. Tanı anında üç hastada uzak metastaz saptandı. FIGO 2009'a göre evrelenen hastaların \%65.5'inin evre-I olduğu saptandı. Cerrahi operasyona giden hastaların \%58.5'i jinekolog-onkolog tarafından ameliyat edildi. Elli iki hasta (\%94.5) total abdominal histerektomi ve iki taraflı salpingooferektomi oldu. Yirmi sekiz hastaya (\%5I) pelvik lenf nodu disseksiyonu yapıldı. Ortalama sağkalım süresi karsinosarkomda 47 ay, leiomyosarkomda 49.6 ay, endometrial stromal sarkomda 84.8 ay, adenosarkomda 68.7 ay olarak hesaplandı. Verilerin toplandığı ocak 2019 tarihine kadar 37 hasta (\%67.3) hayatını kaybetti.

Sonuç: Uterus sarkomları nadir izlenen, erken evrede bile prognozu kötü olan tümörlerdir. Her bir histolojik tip ayrı ayrı değerlendirilmelidir. Uterus sarkomlarında temel tedavi cerrahi olarak kabul görmüştür. Adjuvan tedavilerin rolü tartışmalıdır.

Anahtar Sözcükler: Adenosarkom; endometrial stromal sarkom; karsinosarkom; leiomyosarkom; uterin sarkom. 